\title{
ENDOSCOPIC TREATMENT OF ESOPHAGEAL ANASTOMOTIC STENOSES AND LEAKAGES
}

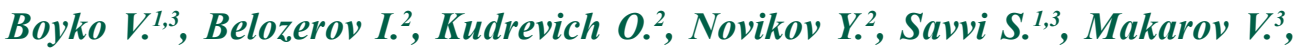 \\ Hroma $V_{.}^{1,3}$, Sarian $I_{.}{ }^{1}$, Korolevska A. ${ }^{3}$, Bytyak S. ${ }^{3}$, Zhidetskyi $V^{1}$ \\ ${ }^{1}$ SI "Zaycev V. T. Institute of General and Urgent Surgery \\ of National Academy of Medical Science of Ukraine", \\ ${ }^{2}$ Karazin V. N. Kharkiv National University \\ ${ }^{3}$ Kharkiv National Medical University \\ https://doi.org/10.35339/ic.7.2.85-88
}

\begin{abstract}
Introduction. Endoscopic stenting of esophageal anastomosis due to anastomotic stenosis or leakage is increasingly being used as one of the most effective, minimally invasive and safe methods of treatment. Materials and methods. This research is based on the experience of treatment of 49 patients with gastric and esophageal cancer who previously were operated at the clinic and had complications such as esophageal anastomotic leakage and stenosis. Anastomotic leakage was observed in 21 cases: 9 patients were with gastroesophageal anastomosis, 12 patients were with esophagointestinal anastomosis. Stenosiss of esophageal anastomosis were observed in 38 cases: 20 patients were with gastroesophageal anastomosis, 18 patients were with esophagointestinal anastomosis. Results. All patients were undergone endoscopic stenting of esophageal anastomosis. The results of using this method of treatment were estimated. Conclusions. Stenting of the esophageal anastomosis by coated selfexpanding stents is a method of choice in the treatment of patients with esophageal anastomotic leakage and stenosis.
\end{abstract}

Key words: anastomotic leakage, anastomotic stenosis, esophageal resection, gastrectomy, stenting of esophageal anastomosis, subtotal proximal gastrectomy.

\section{Introduction}

Gastroesophageal surgery currently remains one of the most technically challenging areas in the digestive tract surgery. It is associated with high rates of postoperative mortality, which ranges after gastrectomy and esophageal resection from 3.3 to $26.1 \%$ [1-3]. The gastroesophageal anastomotic leakage is observed in $2.2-5.91 \%$, esophagointestinal anastomotic leakage - in 6.3$32.0 \%$ of patients [3-8]. Anastomotic stenoses are formed after gastrectomy, resections of the esophagus in $9-30 \%$ of patients [7-13]. Surgical treatment of esophageal anastomotic stenoses has $25 \%$ mortality [10]. In connection with this, in recent years, the priority has been given to the search of more effective minimally invasive

Corresponding Author:

Alla Korolevska, MD,Department of Surgery № 1, Kharkiv National Medical University,

E-mail:korolevska@ukr.net methods of the treatment of esophageal anastomotic stenosis $[9,10,14]$. This has contributed to the creation of certain devices, the development and application of endoscopic technologies, which are currently leading in the treatment of the esophageal anastomotic stenoses [9-11, 15-16]. The used methods of recanalization of the esophageal lumen in the region of cicatricial anastomotic stenosis are the following laser, electro-, argon-plasma coagulation, balloon dilatation and bougienage $[1,2]$. However, despite the fact that in most cases it is possible to expand the lumen in the constriction zone, it is necessary to perform repeated manipulations due to the impossibility of achieving a positive persistent effect in one session [10-11]. Endoscopic stenting of esophageal anastomosis is increasingly being used as one of the most effective, minimally invasive and safe methods of treatment [15-17]. Moreover, the use of this technique in case of esophageal anastomotic leakage often contributes 
to saving of the patient's life [3-6, 14, 17]. For this purpose, self-expanding nitinol stents are used [15-16]. The advantage of these stents is also the presence of anti-migration mechanism in some models. Also, the reflux of gastric or intestinal contents into the esophagus is eliminated by the integrated anti-reflux valve [6,15-17]. In addition, it is believed that the stenting of nitinol selfexpanding stents is a sufficiently effective and safe procedure in treatment of post-operative complications in the esophageal anastomosis region such as anastomotic stenosis and anastomotic leakage [4-6, 14, 17, 18].

\section{Purposes, subjects and methods}

2.1. The purpose of the researche was to analyze the results of the application of stenting of the esophageal anastomoses in patients with esophageal anastomotic stenosiss and leakages.

\subsection{Subjects and Methods}

For the period from 2006 to 2019 we accumulated experience in the use of stents in treatment of post-operative complications in the esophageal anastomosis region such as anastomotic stenosis and anastomotic leakage. Stenting of anastomosis was performed for treatment of 38 patients with esophageal anastomotic stenosis and 21 patients with esophageal anastomotic leakage. 18 patients with cicatricial esophageal anastomotic stenosis previously underwent gastrectomy due to stomach cancer, 4 patients - subtotal proximal gastrectomy due to cancer of the cardiac part of the stomach, 10 patients - esophageal resection with Lewis esophagogastroplasty due to esophageal cancer, 6 patients - esophageal resection with Harlock esophagogastroplasty due to esophageal cancer. 11 patients with esophageal anastomotic leakage previously underwent gastrectomy due to stomach cancer, 4 patients - subtotal proximal gastrectomy due to cancer of the cardiac part of the stomach, 5 patients - esophageal resection with Lewis esophagogastroplasty due to esophageal cancer, 1 patient - combined gastrectomy with gastroplasty by the ileocecal segment.

The stents by M.I.Tech Co., Korea: -29 and Boston Scientific Corp., USA: - 30 were used for the stenting of the esophagus.

At the initial stages, the stenting were performed by the X-ray control with angiographic mode. Patients took in a water soluble radiopaque solution for visualization of anastomotic leakage zone or to determine the beginning of cicatricial stenosis of anastomosis and its length. Radiopaque dermal labels were placed on the skin. Also endoscopic examination was performed. Then string-guide were introduced distally to the anastomosis. The endoscope was removed. After the conduction of the delivery device along the string by the Xray control to the required level, the stent was released. After the final disclosure of the stent, $\mathrm{X}$-ray and endoscopic controls were also performed. With the development of the technology the stenting procedure began to be performed only under visual endoscopic control followed by X-ray control after stent placement.

\section{Conflict of interests}

The authors of the article declare no conflict of interest.

\section{Results}

Successful stenting were performed in 100\% of cases. Clinical effect was achieved in all patients. Immediately after stenting, patients could take the liquid with the subsequent returning to the recommended diet.

Then local complications of patients with esophageal anastomotic leakage were treated: local peritonitis as a result of anastomotic leakage was treated by antibacterial therapy and sanation of the abdominal cavity through the inserted drainages. Treatment of pleural empyema in the zone of leak due to the gastroesophageal anastomotic leakage after esophageal resection in addition to antibiotic therapy included irrigation and drainage of the pleural cavity with the transition to the puncture method under ultrasound monitoring after gradual delimitation of the inflammatory process.

\section{Discussion}

All patients with esophageal anastomotic leakage were discharged from the hospital without signs of anastomotic leakage in a satisfactory state.

All patients with esophageal anastomotic stenoses after stenting had good functional results. Immediately there was a significant reduction of dysphagia. In 3-5 days after stenting dysphagia disappeared completely.

After stenting 4 cases of stent migration were observed: in one case - proximal migration, 3 cases - distal migration. Reposition of the stents were performed with a positive result.

Such treatment results can be comparable with scientific reports of another researchers $[6$, $9,10,17,18]$.

Assessment of patients' life quality and their treatment efficiency consisted in the evaluation of gastroenterological patients' treatment efficiency at the different time periods of treatment by objective and subjective parameters and their integral estimation by the method of evaluating the effectiveness of treatment of patients with gastrointestinal diseases $[19,20]$. 
Assessment before stenting evidenced the lower life quality in all cases. At $10^{\text {th }}$ day after stenting and later on the $20^{\text {th }}$ and $30^{\text {th }}$ day, all objective and subjective life quality parameters confirmed a higher treatment efficiency and better life quality in $34(91,84 \%)$ patients. Lower life quality parameters in $4(8,16 \%)$ cases were caused by post stenting complications [19].

Long-term complications in patients after stenting were absent. This is an evidence of substantially better long-term results of such treatment tactics.

Within the subsequent period after stenting in $1,3,6,9,12$ months all life quality parameters reflected a better life of the patients [19].

\section{Conclusions}

1. Stenting of the esophageal anastomosis by coated self-expanding stents is a method of choice in the treatment of patients with esophageal anastomotic leakage and allows to avoid traumatic operations, especially for the weakened patients. Also it allows to save lives of the patients with these severe complications.

2. Stenting is a very effective miniinvasive method of treatment of the cicatricial esophageal anastomotic stenoses. Especially it is useful when other methods of treatment were unsuccessful (bougienage, balloon dilatation), that allows to restore the lumen of the gastrointestinal tract and improve the quality of life of the patients. Also it is an alternative to traumatic operations of correction of the esophageal anastomotic stenoses.

3. Endoscopic stenting of the esophageal anastomosis by coated self-expanding stents in patients with esophageal anastomotic stenosis or leakage contributes to the improvement of treatment results and life quality of operated patients.

\section{References}

1. Davydov, M.I., Stilidi, I.S. (2007). Rak pishhevoda [Esophageal cancer]. 392 pp.

2. Chernousov, A.F., Polikarpov, S.A., Chernousov, F.A. (2004). Hirurgija raka zheludka [Surgery of gastric cancer]. Moskva: AST. 336 pp.

3. Junemann-Ramirez, M., Awan, M.Y., Khan, Z.M., and Rahamim, J.S. (2005). Anastomotic leakage post-esophagogastrectomy for esophageal carcinoma: retrospective analysis of predictive factors, management and influence on longterm survival in a high volume centre. European Journal of CardioThoracic Surgery. 27, 3-7.

4. Bobrov, O.E., Kirkilevskij, S.I., Buchnev, V.I. (2005). Lechenie nesostojatel'nosti pishhevodnotonkokishechnogo anastomoza [The treatment of esophago-enteral anastomotic leakage]. Tavricheskij mediko-biologicheskij vestnik. 1, 11-13.

5. Bobrov, O.E., Kirkilevskij, S.I., Bechnev, V.I. (2005). Principy lechenija nesostojatel'nosti pishhevodno-tonkokishechnogo anastomoza posle gastrjektomii [Principes of esophago-enteral anastomotic leakage treatment after gastrectomy]. Aktual'ni problemi suchasnoï medicini: Visnik Ukraïns'koï medichnoï stomatologichnoï akademiï. 5, 18-20.

6. Tuebergen, D., Rijcken, E., Mennigen, R., Hopkins, A.M., Senninger, N., Bruewer, M. (2008). Treatment of thoracic esophageal anastomotic leaks and esophageal perforations with endoluminal stents: efficacy and current limitations. J Gastrointest Surg. 12, 1168-1176.

7. Shvyreva, N.E., Mizikov, V.M., Stamov, V.I., Pejkarova, A.V. (2011). Nutritivnyj status, anestezija i rannie posleoperacionnye oslozhnenija u pacientov pri radikal'nyh operacijah na pishhevode [Nutritive status, anesthesia, and early postoperative complications in patients with radical esophageal surgery]. Anesteziologija i reanimatologija. 3, 69-73.

8. Orringer, M.B., Marshall, B., Iannettoni, M.D. (2000). Eliminating the cervical esophagogastric anastomotic leak with a side-to-side stapled anastomosis. The Journal of Thoracic and Cardiovascular Surgery. 2. 277-288.

9. Gallinger, Ju.I., Godzhello, Je.A. (2000). Jendoskopicheskoe lechenie rubcovyh stenozov pishhevoda [Endoscopic treatment of cicatricial esophageal stenosis]. Jendoskopicheskaja hirurgija. 5, 33-39.

10. Kuvshinov, Ju.P., Poddubnyj, B.K, Efimov, O.N., Stilidi, I.S. (2000). Jendoskopicheskaja hirurgija opuholevyh i posleoperacionnyh stenozov u bol'nyh rakom pishhevoda i zheludka [Endoscopic surgery of tumoral and postoperative stenosis in patient withesophageal and gastric cancer]. Sovremennaja onkologija. 3. 72-78.

11. Hadzhibaev, A.M., Nizahodzhaev, Z.M., Strusskij, L.P., Madrahimov, N.Z. (1999). Jendoskopicheskaja jelektrokoaguljacija $v$ lechenii rubcovyh suzhenij pishhevodnyh anastomozov [Endoscopic electrocoagulation in treatment of cicatricial stenosis of esophagus]. Tezisy dokladov. Moskva. 310-311. 
12.Singhal, S., Hasan, S.S., Cohen, D.C. (2013). Multi-disciplinary approach for management of refractory benign occlusive esophageal strictures. Therapeutic advances in gastroenterology.6(5), 365370.

13.Chang, A.C., Orringer, M.B. (2007). Management of the cervical esophagogastric anastomotic stricture. The Journal of Thoracic and Cardiovascular Surgery. 19. 66-71.

14.Ganul, V.L., Kirkilevskij, S.I. (2003). Rak pishhevoda: rukovodstvo dlja onkologov i hirurgov [Esophageal cancer: handbook for the oncologists and surgeons]. $200 \mathrm{pp}$.

15. Tsuda, S. Endoscopic treatment of complications after Gastrointestinal Surgery. Society of American Gastrointestinal and Endoscopic Surgeons. Retrieved from: https://www.sages.org/wiki/endoscopicmanagement-complications/.

16. Aimore Bonin, E., Verschoor, B., Hoffmann Silva, F. (2019). Stents in Gastrointestinal Diseases. Advanced Endoscopy /. DOI: http://dx.doi.org/10.5772/intechopen.88117.

17.Radecke, K., Gerken, G., Treichel, U. (2005). Impact of self-expanding, plastic esophageal stent on various esophageal stenoses, fistulas, and leakages: a single-center experience in 39 patients. Gastrointest. Endosc. 7., 812-818.

18.Parekh, K., Iannettoni, M.D. (2007). Complications of esophageal resection and reconstruction. Seminars in Thoracic and Cardiovascular Surgery. 19, 79-88.

19.Bojko, V.V., Savvi, S.O., Zhidec'kij, V.V., Korolevs'ka, A.Ju., Bikulova, D.U. (2015). Patent Ukraïni № 103176 Sposib ocinki efektivnosti likuvannja hvorih z gastroenterologichnimi zahvorjuvannjami [Patent of Ukraine № 103176 The method of evaluating the effectiveness of treatment of patients with gastrointestinal diseases]. Bjuleten'. 23, 26 pp.

20.Novik, A.A., Matveev, S.A., Popova, T.N. (2000). Ocenka kachestva zhizni v medicine [Life quality assessment in medicine]. Klinicheskaja medicina. 2, 10-13.

Received: 04-Feb-2020

Accepted: 06-Jun-2020 